\title{
Bioremediation of heavy metals using an endophytic bacterium Paenibacillus sp. RM isolated from the roots of Tridax procumbens
}

\author{
M. Govarthanan ${ }^{1}$ R. Mythili' ${ }^{2}$ T. Selvankumar ${ }^{2} \cdot$ S. Kamala-Kannan ${ }^{3}$. \\ A. Rajasekar ${ }^{4}$ Young-Cheol Chang ${ }^{1}$
}

Received: 20 September 2016/ Accepted: 1 November 2016/Published online: 12 November 2016

(c) The Author(s) 2016. This article is published with open access at Springerlink.com

\begin{abstract}
The aim of the present study was to assess the bioremediation potential of endophytic bacteria isolated from roots of Tridax procumbens plant. Five bacterial endophytes were isolated and subsequently tested for minimal inhibitory concentration (MIC) against different heavy metals. Amongst the five isolates, strain RM exhibited the highest resistance to copper $(750 \mathrm{mg} / \mathrm{l})$, followed by zinc $(500 \mathrm{mg} / \mathrm{l})$, lead $(450 \mathrm{mg} / \mathrm{l})$, and arsenic (400 mg/l). Phylogenetic analysis of the $16 \mathrm{~S}$ rDNA sequence suggested that strain RM was a member of genus Paneibacillus. Strain RM also had the capacity to produce secondary metabolites, indole acetic acid, siderophores, 1-aminocyclopropane-1-carboxylate (ACC) deaminase, and biosurfactant and solubilize phosphate. The growth kinetics of strain RM was altered slightly in the presence of metal stress. Temperature and $\mathrm{pH}$ influenced the metal removal rate. The results suggest that strain RM
\end{abstract}

\footnotetext{
M. Govarthanan

gova.muthu@gmail.com

Young-Cheol Chang

ychang@mmm.muroran-it.ac.jp

1 Department of Applied Sciences, College of Environmental Technology, Muroran Institute of Technology, 27-1, Mizumoto, Muroran, Hokkaido 050-8585, Japan

2 PG and Research Department of Biotechnology, Mahendra Arts and Science College (Autonomous), Kalippatti, Namakkal 637501, Tamil Nadu, India

3 Division of Biotechnology, Advanced Institute of Environment and Bioscience, College of Environmental and Bioresource Sciences, Chonbuk National University, Iksan 54596, South Korea

4 Environmental Molecular Microbiology Research Laboratory, Department of Biotechnology, Thiruvalluvar University, Serkadu, Vellore 632115, Tamil Nadu, India
}

can survive under the high concentration of heavy metals and has been identified as a potential candidate for application in bioremediation of heavy metals in contaminated environments.

Keywords Bioremediation - Endophytes - Heavy metals · Tridax procumbens

\section{Introduction}

Heavy metal contamination of soil and water has become a serious problem worldwide. Bioconcentration and subsequent biomagnification of heavy metals and high levels of toxicity they impart to biological organisms indicate the necessity for the removal of heavy metals from contaminated soil and water (Govarthanan et al. 2014). Several physical, chemical, and biological methods have been proposed for the removal of heavy metals from contaminated soil and water (Shi et al. 2009), of which bacteriabased bioremediation is considered as a promising and viable method. Bacteria-based bioremediation is less expensive and eco-friendly (Govarthanan et al. 2015a), but is highly influenced by several factors, such as survival of bacteria in contaminated soil or water, influence of abiotic factors on the growth of bacteria, mechanism of metal detoxification, expression rate of metal detoxificiation genes, and influence of pollutants on bacterial activity (Suja et al. 2014; Govarthanan et al. 2015b; Praburaman et al. 2015).

In the past few years, attention has been concentrated on the bioremediation of heavy metals using endophytic plantgrowth-promoting bacteria (Sun et al. 2010; Ma et al. 2015). Endophytes or endophytic bacteria colonise internal tissues of normal healthy plants with little negative effects 
on the host (Schulz and Boyle 2006). The endophytic bacterial strains are ubiquitously distributed in a wide range of plant species, and have been found in plant organs, such as leaves, stem, root, flowers, and fruits (Compant et al. 2011; Sun et al. 2010). These bacteria play a significant role in plant growth and development by producing plant-growth-promoting substances, such as indole-3-acetic acid (IAA), siderophores, and 1-aminocyclopropane-1carboxylate (ACC) deaminase (Tiwari et al. 2016). They also produce biosurfactants and extracellular polymeric substances that prevent, moderate, or nullify the toxicity of heavy metals in these plants (Rajkumar et al. 2009; Weyens et al. 2010). Zhu et al. (2014) reported that endophytic bacteria isolated from hyperaccumulator plants Pteris vittata and Pteris multifida showed significant metal removal and plant-growth-promoting properties.

Tridax procumbens is a widespread weed with massive root system and rapid growth rate, and is commonly seen throughout the year (Khandare et al. 2011). Kumar et al. (2013) reported that $T$. procumbens effectively removed $\mathrm{Cr}, \mathrm{Cu}, \mathrm{Ni}, \mathrm{Pb}$, and $\mathrm{Cd}$ from soil contaminated with industrial wastes. However, the endophytic bacterial population in the roots of $T$. procumbens roots and their heavy metal bioremediation potential has not been reported. Hence, the aim of the present study was (1) to isolate metal-resistant endophytic bacteria from roots of $T$. procumbens, (2) to evaluate multi-metal tolerance and plant-growth-promoting characteristics of the isolates, (3) to assess bioremediation potential of the isolate, and (4) to optimise experimental variables, such as $\mathrm{pH}$ and temperature for enhanced bioremediation.

\section{Materials and methods}

\section{Isolation of heavy metal-resistant endophytic bacteria from Tridax procumbens root}

Healthy $T$. procumbens plants were collected randomly from agricultural land, and plant sample was washed with tap water followed by several rinses with sterile water. The washed plant was dissected into roots and stems with a sterile scalpel. Root samples were surface sterilised with 95\% ethanol and 3\% hypochlorite solution for 2-3 min. Surface sterilised root samples were again washed several times in sterile water to remove the sterilization agents. Sterilised root tissue ( $1 \mathrm{~g}$ fresh weight) was ground in a mortar and pestle with $5 \mathrm{ml}$ saline $(0.85 \% \mathrm{NaCl})$. The saline suspension was serially diluted and plated using the spread plate technique onto Nutrient Agar (Hi-Media, India) plates. The plates were incubated at $35 \pm 2{ }^{\circ} \mathrm{C}$ for $48 \mathrm{~h}$ and observed for bacterial growth on agar surface.
Morphologically distinct colonies were purified and stored at $4{ }^{\circ} \mathrm{C}$ for further studies.

\section{Heavy metal tolerance}

Heavy metal tolerance levels of isolates were assessed by agar-dilution method. Briefly, the isolates were inoculated in Luria-Bertani (LB) agar plates containing different concentrations of heavy metals ( $\mathrm{As}, \mathrm{Cu}, \mathrm{Zn}$, and $\mathrm{Pb}$ ) ranging from 100 to $750 \mathrm{mg} / \mathrm{l}$. The plates were incubated overnight at $25{ }^{\circ} \mathrm{C}$ and observed for bacterial growth. Lowest concentration of the metal that completely inhibited the growth of bacteria was considered as minimal inhibitory concentration (MIC). All the metal salts were added to LB agar after autoclaving and cooling to $50{ }^{\circ} \mathrm{C}$ from filter-sterilised stock solutions (Kamala-Kannan and Krishnamoorthy 2006).

\section{Plant-growth-promoting properties of the isolates}

Indole acetic acid (IAA) production was analysed according to Gordon and Weber. Freshly grown bacterial culture was inoculated into Dworkin and Foster (DF) minimal medium supplemented with $0.5 \mathrm{mg} / \mathrm{ml}$ of tryptophan and incubated at $30{ }^{\circ} \mathrm{C}$ for $48 \mathrm{~h}$. After incubation, $1 \mathrm{ml}$ bacterial culture was mixed with $2 \mathrm{ml}$ Salkowski's reagent (150 ml conc. $\mathrm{H}_{2} \mathrm{SO}_{4}, 250 \mathrm{ml}$ distilled water, and $7.5 \mathrm{ml}$ $0.5 \mathrm{MFeCl}_{3} \cdot 6 \mathrm{H}_{2} \mathrm{O}$ ), and allowed to stand at $37^{\circ} \mathrm{C}$ for 20 min. Appearance of a pink colour in the tubes indicated IAA production (Gordon and Weber 1951).

Siderophore production efficiency of the isolates was tested according to Schwyn and Neilands by Chrome Azurol S agar (CAS) method. Briefly, $1.0 \mathrm{ml}$ CAS solution was added to $1.0 \mathrm{ml}$ filtered supernatant of the isolate. The siderophore production was estimated by the colour change from blue to orange. Tubes in CAS solution without the supernatant were used as a control.

The 1-aminocyclopropane-1-carboxylate (ACC) deaminase activity of the isolated strains was determined according to Praburaman et al. (2015). In brief, the isolate was inoculated in DF minimal medium supplemented with $3 \mathrm{mM}$ ACC as the nitrogen source. The tubes were incubated at $37{ }^{\circ} \mathrm{C}$ on a rotatory shaker at $200 \mathrm{rpm}$ for $48 \mathrm{~h}$. The development of turbidity in the tubes was considered ACC deaminase positive.

Phosphate solubilization efficiency of the isolates was assessed using Pikovskaya medium (Pikovskaya 1948). Briefly, fresh bacterial culture was inoculated into Pikovskaya agar containing inorganic phosphate and incubated at $30{ }^{\circ} \mathrm{C}$ for $48 \mathrm{~h}$. Formation of a clear zone around the bacterial colony was considered as an index of solubilization of mineral phosphate. 
Biosurfactant producing ability of the endophytes was identified using oil displacement test and emulsification assay. The emulsification assay was calculated using emulsification index:

E24 (Emulsification index)

$=\frac{\text { Height of emulsification layer developed }}{\text { Total height of liquid medium }} \times 100$.

\section{Identification of the potential endophytic bacteria}

DNA was extracted from strain RM, using QIAGEN (CA, USA) DNA extraction kit, and its concentration was determined using a UV-Vis spectrophotometer (NanoDrop 2000). Fragments of $16 \mathrm{~S}$ rDNA were amplified using universal primers $27 \mathrm{f}$ (5'-AGAGTTTGATCCTGGCTC AG- $\left.3^{\prime}\right)$ and $1492 \mathrm{r}\left(5^{\prime}\right.$-CCCCGTCAATTCATTTGAGTT $\mathrm{T}-3^{\prime}$ ). PCR product was purified using a QIAGEN PCR purification kit and sequenced using an automated $\mathrm{ABI}$ PRISM 3700 sequencer (USA). The obtained 16S rRNA sequence was compared against the available sequence database using BLAST program in NCBI website. Phylogenetic tree was constructed using neighbour-joining distance method by software Mega 6.0.

\section{Effect of heavy metals on growth kinetics of the isolate}

Strain RM was inoculated into $250 \mathrm{ml}$ Erlenmeyer flasks containing $100 \mathrm{ml}$ of LB broth and incubated in a shaking incubator at $200 \mathrm{rpm}$ for $24 \mathrm{~h}$ at $37{ }^{\circ} \mathrm{C}$. At the stage of the late exponential phase, $100 \mathrm{mg} / \mathrm{l}$ of the metal solutions $(\mathrm{Cu}, \mathrm{Pb}, \mathrm{Zn}$, and $\mathrm{As})$ were inoculated into the culture flasks. Bacterial growth was determined by measuring the optical density $(600 \mathrm{~nm})(\mathrm{UV}-1800$, Shimadzu, Japan) at prescribed time intervals $(0,8,12,24$, and $48 \mathrm{~h})$. All the experiments were performed in triplicates. Growth of the isolate without metals was considered as the control for this experiment.

\section{Removal of metals at different $\mathrm{pH}$ and temperature conditions}

The effect of $\mathrm{pH}$ on the removal of heavy metals was determined at various $\mathrm{pH}$ levels ranging from 6 to 9. In brief, $10 \mathrm{ml}$ of the bacterial suspension was aseptically inoculated into $250 \mathrm{ml}$ Erlenmeyer flasks containing $100 \mathrm{ml}$ of metal solutions $(\mathrm{Cu}, \mathrm{Pb}, \mathrm{Zn}$, and $\mathrm{As}$ ) (initial metal concentration $50 \mathrm{mg} / \mathrm{l}$ ) individually. The flasks were incubated in a shaking incubator $(200 \mathrm{rpm})$ at $37{ }^{\circ} \mathrm{C}$, and the samples were collected after $48 \mathrm{~h}$ of incubation. The samples were centrifuged $(10,000 \mathrm{rpm}$ for $5 \mathrm{~min})$, filtered $(0.22 \mu \mathrm{m})$, and analysed for the residual heavy metal concentration using atomic adsorption spectroscopy (AAS) (Thermo Scientific ${ }^{\mathrm{TM}}$ iCE $^{\mathrm{TM}}$ 3500). Similarly, the effect of temperature was measured by incubating the flasks at different temperatures $\left(30,35\right.$, and $\left.37^{\circ} \mathrm{C}\right)$. Flask without bacteria was used as a control for this experiment. All the experiments were repeated for three times, and each sample was tested in triplicate.

\section{Bioremediation of $\mathrm{Cu}, \mathrm{Pb}, \mathrm{Zn}$, and $\mathrm{As}$ by the isolate at optimum $\mathrm{pH}$ and temperature}

Batch experiments were performed to assess the bioremediation potential of the isolate RM. In brief, strain RM was inoculated in $250 \mathrm{ml}$ Erlenmeyer flasks containing $100 \mathrm{ml}$ of $\mathrm{LB}$ broth amended with $50 \mathrm{mg} / \mathrm{l}$ of $\mathrm{Cu}, \mathrm{Pb}, \mathrm{Zn}$, or $\mathrm{As}$ individually. The flasks were incubated at $37{ }^{\circ} \mathrm{C}$ and agitated at $200 \mathrm{rpm}$ for $48 \mathrm{~h}$. Samples were collected at after $48 \mathrm{~h}$, centrifuged $(10,000 \mathrm{rpm}$ for $5 \mathrm{~min})$, filtered $(0.22 \mu \mathrm{m})$, and analysed for residual heavy metal concentration using AAS.

\section{Results and discussion}

Bioremediation has been widely accepted as an ecofriendly approach for the removal of metals from contaminated soil and water. In the present study, an endophytic bacteria isolated from $T$. procumbens was assessed for their heavy metal bioremediation potential. Five heavy metal-resistant endophytic bacterial strains were isolated from roots of $T$. procumbens, and the isolates were screened for metal resistance on LB agar plates (1/4 strength) supplemented with $\mathrm{Cu}, \mathrm{Pb}, \mathrm{Zn}$, or As. All the five endophytes showed resistance to the metals, while strain RM showed the highest MIC $(\mathrm{Cu} ; 750 \mathrm{mg} / \mathrm{l})$ strength to all the studied metals. Minimal inhibitory concentration of the isolates is shown in Table 1. The metal resistance appears to be little lower than that typically reported for other plants (Shin et al. 2012). However, a direct comparison of our results with other studies is difficult, because various biotic and abiotic factors highly influence the bacterial

Table 1 Multi-metal resistance pattern of the endophytes isolated from the roots of Tridax procumbens

\begin{tabular}{lllll}
\hline Bacterial isolates & As (mg/l) & $\mathrm{Zn} \mathrm{(mg/l)}$ & $\mathrm{Cu}(\mathrm{mg} / \mathrm{l})$ & $\mathrm{Pb}(\mathrm{mg} / \mathrm{l})$ \\
\hline RM & 400 & 500 & 750 & 450 \\
RM1 & 200 & 350 & 150 & 100 \\
RM2 & 200 & 250 & 200 & 100 \\
RM3 & 150 & 200 & 350 & 300 \\
RM4 & 200 & 150 & 200 & 250 \\
\hline
\end{tabular}


Table 2 Plant-growth-promoting characteristics of the isolates

\begin{tabular}{llclll}
\hline Bacterial isolates & $\begin{array}{l}\text { Siderophore } \\
\text { production }\end{array}$ & IAA (mg/l) & ACC & $\begin{array}{l}\text { Phosphate } \\
\text { solubilization }\end{array}$ \\
\hline RM & + & $17.2 \pm 1.2$ & + & + & $\begin{array}{l}\text { Biosurfactant } \\
\text { production }\end{array}$ \\
RM1 & - & $10 \pm 1$ & + & - & - \\
RM2 & - & $8 \pm 1$ & - & + & - \\
RM3 & + & $8.2 \pm 2$ & - & + & - \\
RM4 & - & $11.1 \pm 3$ & + & - & - \\
\hline
\end{tabular}

$(+)$ and $(-)$ symbols indicates the presence or absence of different plant-growth-promoting characteristics in the isolated endophytes

metal detoxification rate and bioavailability of metals to the bacterial system (Kamala-Kannan and Krishnamoorthy 2006).

Endophytic bacteria have the ability to improve growth and remediation of heavy metal contaminated environments by producing IAA and other plant-growth-promoting factors (Zhang et al. 2011). Thus, the isolates were screened for their plant-growth-promoting properties. All the isolates successfully produced IAA from tryptophan (Table 2). Strain RM exhibited maximum IAA production $(17.2 \mathrm{mg} / \mathrm{l})$. Recent studies have reported endophytes isolated from the roots of $P$. vittata to produce $18.5 \mathrm{mg} / \mathrm{l}$ of IAA (Zhu et al. 2014; Tiwari et al. 2016). Siderophores are high-affinity iron-chelating proteins that play a vital iron in making iron available to the bacterial system. Thus, the isolates were screened for siderophore production, and the results are depicted in Table 2. Among the five isolates, strain RM3 and strain RM produced siderophores. The results are in accordance with previous study that reported variations in siderophore production among endophytic bacteria (Tiwari et al. 2016). The isolates RM1, RM4, and RM produced ACC deaminase (see Table 2), an important enzyme that increases availability of nitrogen sources to the bacterial system by degrading ACC into $\alpha$-ketobutyrate and ammonia, and also regulates ethylene levels in plant systems. The results are in agreement with previous study reporting ACC deaminase activity of endophytic bacteria in Phytolacca Americana (Zhang et al. 2015). Phosphate solubilization potential is very common among endophytic bacteria (Ghosh et al. 2016). In this study, a clear zone around the isolates RM2, RM3, and RM colonies in Pikovskaya medium indicated the phosphate solubilization potential of the isolates. The isolates may solubilise the phosphate either by producing enzymes or by organic acids.

All the isolates were also screened for their biosurfactant production ability. Among the five isolates, strain RM showed biosurfactant producing ability. Biosurfactant production is considered as an attracting characteristic of endophytes for environmental application, because biosurfactants detoxify the pollutants present in the contaminated soil and water (De Franca et al. 2015). Based on its multi-metal resistance mechanisms, plant-growth-promoting characteristics, and biosurfactant production efficiency, strain RM was selected for heavy metal bioremediation studies.

PCR amplification of the $16 \mathrm{~S}$ rDNA of strain RM resulted in a predicted $1384 \mathrm{bp}$ amplicon. The consensus 16S rDNA sequences of strain RM exhibited $100 \%$ similarity with Paenibacillus brasilensis. The partial 16S rDNA of strain RM was deposited in GenBank (Accession Number: KX529114). A phylogenetic tree was derived from the partial 16S rDNA sequences of strain RM with existing sequences in the NCBI database, and the results are shown in Fig. 1. The results further confirm the identity

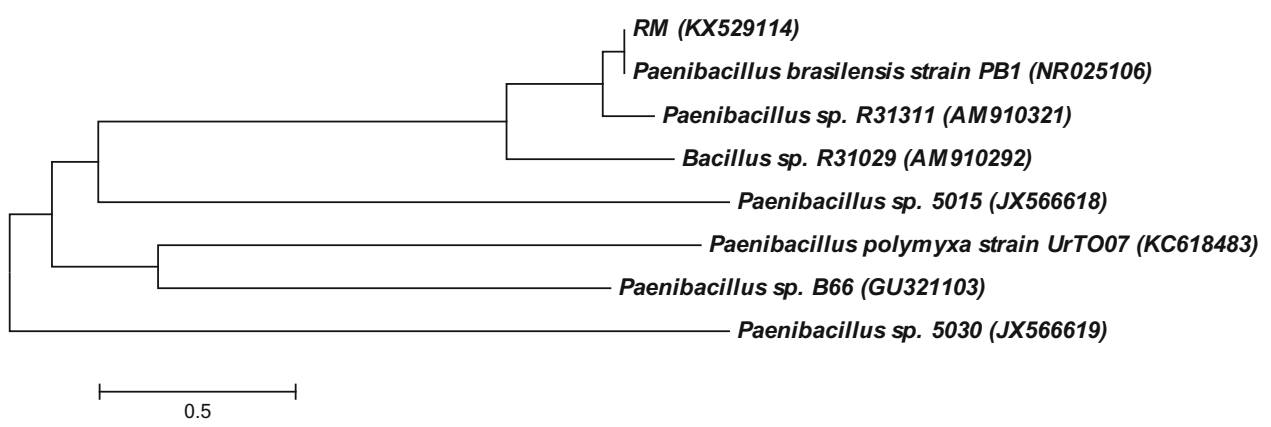

Fig. 1 Neighbour-joining tree constructed using Mega 6.0 showing the phylogenetic relationship of $16 \mathrm{~S}$ rDNA sequence of isolated strain Paenibacillus sp. RM from closely related sequences from GenBank.
Accession numbers at the GenBank of National Centre for Biotechnology Information (NCBI) are shown in parenthesis 
of the isolate with Paenibacillus sp. Barzanti et al. (2007) isolated metal resistant and plant-growth-promoting endophytic Paenibacillus sp. from the roots of Ni-hyperaccumulator Alyssum bertolonii. The growth profile of strain $\mathrm{RM}$ in the presence of metals is presented in Fig. 2. A minor difference in the growth response was observed according to the metal. The differences in the growth profile could be associated with the toxicity and bioavailability of metals (Govarthanan et al. 2015a).

$\mathrm{Cu}, \mathrm{Pb}, \mathrm{Zn}$, and As removal efficiency of Paenibacillus sp. RM at different $\mathrm{pH}$ levels was assessed, and the results are presented in Fig. 3. The removal rates of all the four metals (Cu: $61.4 \%$, As: $37.3 \%$, Zn: $54.5 \%$, and Pb: $37.5 \%$ ) were high at $\mathrm{pH}$ 7.0. A minor decrease in the metal removal rate was observed at $\mathrm{pH}$ 6.0. It has been reported that in acidic $\mathrm{pH}$, association of hydronium ions with the cell

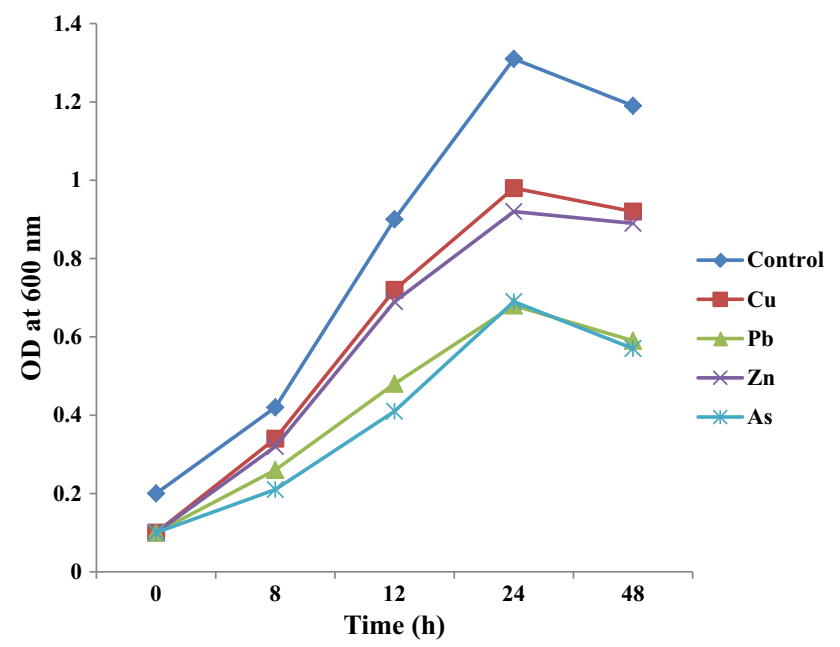

Fig. 2 Growth kinetics of Paenibacillus sp. RM using various metals $(\mathrm{Cu}, \mathrm{Pb}, \mathrm{Zn}$, and $\mathrm{As})$ at $100 \mathrm{mg} / \mathrm{l}$

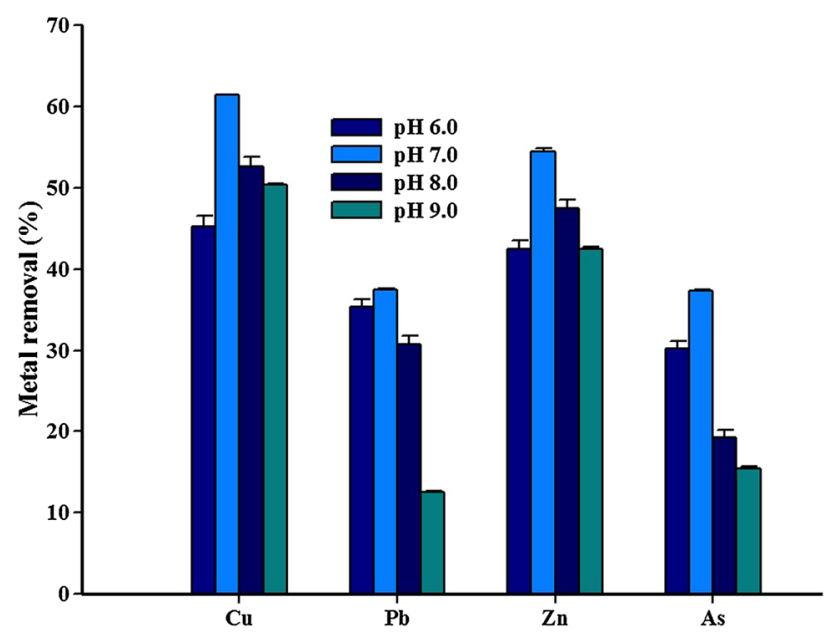

Fig. 3 Influence of $\mathrm{pH}$ on $\mathrm{Cu}, \mathrm{Pb}, \mathrm{Zn}$, and $\mathrm{As}$ removal by the isolate Paenibacillus sp. RM surface creates reduction of negative charge intensity on the bacterial cell wall resulting in the reduction or inhibition of the binding of metal ions (Khalid et al. 2011). Fourest et al. (1994) reported that the functional groups on the bacteria may become positively charged and may not interact with the metal ions at acidic $\mathrm{pH}$. Similarly, a minor decrease in metal removal capacity was observed with the increase in $\mathrm{pH}$ up to 9.0. The decreased removal rate at alkaline $\mathrm{pH}$ can be attributed to the growth response of the isolate under $\mathrm{pH}$ stress. The limited growth of isolates at alkaline $\mathrm{pH}$ reduces the overall uptake of metals (Guo et al. 2010). The results of this study further support the importance of solution $\mathrm{pH}$ in metal removal from aqueous solution.

Understanding the impact of temperature variations on the metal removal efficiency of bacteria may provide us with valuable insight into the mechanism of interaction between the metal-resistant bacteria and the corresponding metal (Zhou et al. 2013). The metal removal efficiency of Paenibacillus sp. was tested with different temperature conditions, as temperature is an important parameter in biological reduction of heavy metals, and the results are presented in Fig. 4. It could be seen from the results of batch experiments that the removal of $\mathrm{Cu}, \mathrm{Pb}, \mathrm{Zn}$, and $\mathrm{As}$ increased with increasing temperature up to $37{ }^{\circ} \mathrm{C}$, but the removal efficiency of all the metal ions decreased slightly at $40{ }^{\circ} \mathrm{C}$. The removal efficiencies of heavy metals at $37{ }^{\circ} \mathrm{C}$ were $\mathrm{Cu}, 59.4 \% ; \mathrm{Pb}, 29.5 \%$; $\mathrm{Zn}, 51.4 \%$; and $\mathrm{As}$, $27.4 \%$. $\mathrm{Cu}$ and $\mathrm{Zn}$ were significantly removed at $37^{\circ} \mathrm{C}$ compared with $\mathrm{Pb}$ and As. Zhou et al. (2013) reported the biological removal of $\mathrm{Cu}$ and $\mathrm{Zn}$ to be highly influenced by temperature. The results from our study indicate that the optimum temperature and $\mathrm{pH}$ for the metal removal were $37^{\circ} \mathrm{C}$ and 7.0. Thus, the optimum metal removal efficiency of the isolate Paenibacillus sp. RM was assessed under

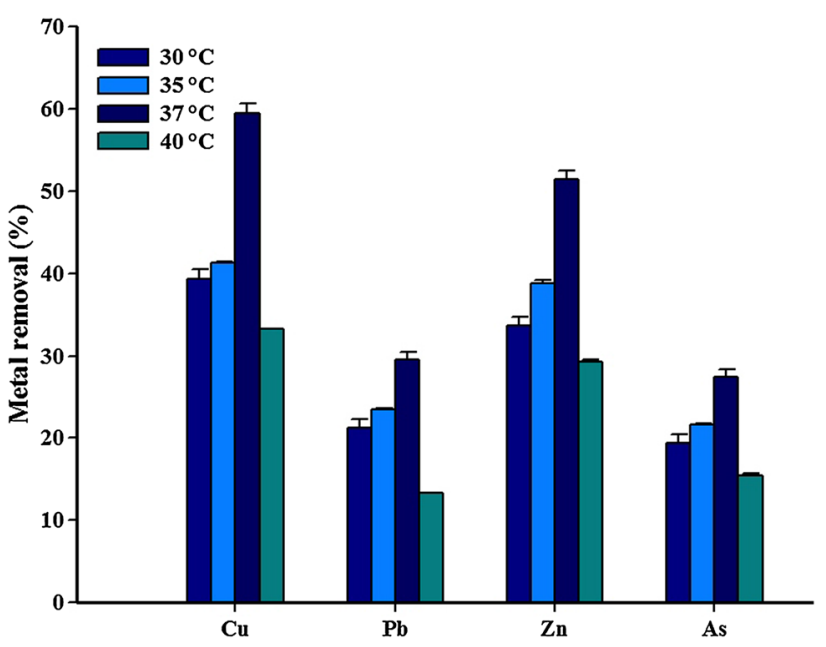

Fig. 4 Influence of temperature on $\mathrm{Cu}, \mathrm{Pb}, \mathrm{Zn}$, and $\mathrm{As}$ removal by the isolate Paenibacillus sp. RM 


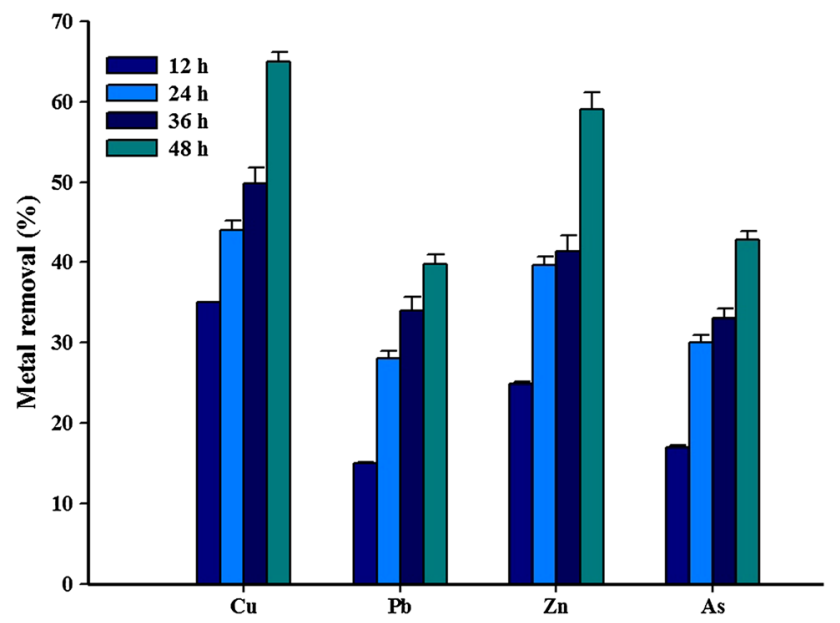

Fig. 5 Influence of optimum $\mathrm{pH}$ and temperature on $\mathrm{Cu}, \mathrm{Pb}, \mathrm{Zn}$, and As removal by the isolate Paenibacillus sp. RM

optimal conditions, and the results are presented in Fig. 5. Expectedly, all the four metals were removed at higher concentration. The maximum removal rate $(65.0 \%)$ of $\mathrm{Cu}$ was observed at $48 \mathrm{~h}$ of incubation, and the minimum removal rate $(15.1 \%)$ of $\mathrm{Pb}$ was observed at $12 \mathrm{~h}$. The bioremediation rate of living metal-resistant bacteria should be strongly dependent on the population of cells at optimal growth conditions (Guo et al. 2010). The results from this study indicated that $\mathrm{pH}$ and temperature play a major role in the survival of and metal removal potential of the RM isolate.

\section{Conclusion}

The endophytic bacteria Paenibacillus sp. RM isolated from $T$. procumbens showed a significant resistance to $\mathrm{Cu}$, $\mathrm{Zn}$, As, and $\mathrm{Pb}$. Bioremediation studies with batch experiments showed that the isolate Paenibacillus sp. RM caused high removal of $\mathrm{Cu}(59.4 \%)$ followed by $\mathrm{Zn}$ (51.4). The results indicated the potential role of endophytic bacteria Paenibacillus sp. RM in removing multiple metals. Multi-metal resistance and plant-growth-promoting characteristics suggest that the strain Paenibacillus sp. RM could be used as a potential candidate for the bioremediation of heavy metals.

\section{Compliance with ethical standards}

Conflict of interest The authors declare that they have no conflict of interests.

Open Access This article is distributed under the terms of the Creative Commons Attribution 4.0 International License (http:// creativecommons.org/licenses/by/4.0/), which permits unrestricted use, distribution, and reproduction in any medium, provided you give appropriate credit to the original author(s) and the source, provide a link to the Creative Commons license, and indicate if changes were made.

\section{References}

Barzanti R, Ozino F, Bazzicalupo M, Gabbrielli R, Galardi F, Gonnelli C, Mengoni A (2007) Isolation and characterization of endophytic bacteria from the nickel hyperaccumulator plant Alyssum bertolonii. Microb Ecol 53:306-316

Compant S, Mitter B, Colli-Mull JG, Gangl H, Sessitsch A (2011) Endophytes of grapevine flowers, berries, and seeds: identification of cultivable bacteria, comparison with other plant parts, and visualization of niches of colonization. Microb Ecol 62:88-197

De Franca IWL, Lima AP, Lemos JAM, Lemos CGF, MacielMelo VM, de Santana HB, Goncalves LRB (2015) Production of a biosurfactant by Bacillus subtilis ICA56 aiming bioremediation of impacted soils. Catal Today 255:10-15

Fourest E, Canal C, Roux JC (1994) Improvement of heavy metal biosorption by mycelial dead biomasses (Rhizopus arrhizus, Mucor miehei and Penicillium chrysogenum): $\mathrm{pH}$ control and cationic activation. FEMS Microbiol Rev 14:325-332

Ghosh R, Barman S, Mukherjee R, Mandal NC (2016) Role of phosphate solubilizing Burkholderia spp. for successful colonization and growth promotion of Lycopodium cernuumL. (Lycopodiaceae) in lateritic belt of Birbhum district of West Bengal, India. Microbiol Res 183:80-91

Gordon SA, Weber RP (1951) Colorimetric estimation of indole acetic acid. Plant Physiol 26:192-195

Govarthanan M, Lee GW, Park JH, Kim JS, Lim SS, Seo SK, Cho M, Myung H, Kamala-Kannan S, Oh BT (2014) Bioleaching characteristics, influencing factors of $\mathrm{Cu}$ solubilization and survival of Herbaspirillum sp. GW103 in Cu contaminated mine soil. Chemosphere 109:42-48

Govarthanan M, Park SH, Park YJ, Myung H, Krishnamurthy RR, Lee SH, Lovanh N, Kamala-Kannan S, Oh BT (2015a) a) Lead biotransformation potential of allochthonous Bacillus sp. SKK11 with sesame oil cake extract in mine soil. RSC Adv 5:54564-54570

Govarthanan M, Lee SM, Kamala-Kannan S, Oh BT (2015b) b) characterization, real-time quantification and in silico modeling of arsenate reductase (arsC) genes in arsenic- resistant Herbaspirillum sp. GW103. Res Microbiol 166:196-204

Guo H, Luo S, Chen L, Xiao X, Xi Q, Wei W, Zeng G, Liu C, Wan Y, Chen J, He Y (2010) Bioremediation of heavy metals by growing hyperaccumulaor endophytic bacterium Bacillus sp. L14. Bioresour Technol 101:8599-8605

Kamala-Kannan S, Krishnamoorthy R (2006) Isolation of mercury resistant bacteria and influence of abiotic factors on bioavailability of mercury - a case study in Pulicat Lake north of Chennai, south east India. Sci Total Environ 367:341-353

Khalid A, Hussein Sedky HA, Hassan JHJ (2011) Potential capacity of Beauveria bassiana and Metarhizium anisopliae in the biosorption of $\mathrm{Cd}^{+}$and $\mathrm{Pb}^{+}$. J Gen Appl Microbiol 57:347-355

Khandare RV, Kabra AN, Kurade MB, Govindwar SP (2011) Phytoremediation potential of Portulaca grandiflora Hook. (Moss-Rose) in degrading a sulfonated diazo reactive dye Navy Blue HE2R (Reactive Blue 172). Bioresour Technol 102:6774-6777

Kumar N, Bauddh K, Kumar S, Dwivedi N, Singh DP, Barman SC (2013) Accumulation of metals in weed species grown on the soil contaminated with industrial waste and their phytoremediation potential. Ecol Eng 61:491-495 
Ma Y, Oliveira RS, Nai F, Rajkumar M, Luo Y, Rocha I, Freitas H (2015) The hyperaccumulator Sedum plumbizincicola harbors metal-resistant endophytic bacteria that improve its phytoextraction capacity in multi-metal contaminated soil. J Environ Manage 156:62-69

Pikovskaya RI (1948) Mobilization of phosphorus in soil in connection with vital activity of some microbial species. Mikrobiologiya 17:363-370

Praburaman L, Hyun M, Govarthanan M, Lee KJ, Kamala-Kannan S, Oh BT (2015) Effect of heavy metals on acdS gene expression in Herbaspirillium sp. GW103 isolated from rhizosphere soil. J Basic Microbiol 55:1232-1238

Rajkumar M, Ae N, Freitas H (2009) Endophytic bacteria and their potential to enhance heavy metal phytoextraction. Chemosphere 77:153-160

Schulz B, Boyle C (2006) What are endophytes? In: Schulz BJE, Boyle CJC, Sieber TN (eds) Microbial root endophytes. Springer, Berlin, pp 1-13

Shi W, Shao H, Li H, Shao M, Du S (2009) Progress in the remediation of hazardous heavy metal-polluted soils by natural zeolite. J Hazard Mater 170:1-6

Shin MN, Shim J, You Y, Myung H, Bang KS, Cho M, KamalaKannan S, Oh BT (2012) Characterization of lead resistant endophytic Bacillus sp. MN3-4 and its potential for promoting lead accumulation in metal hyper accumulator Alnus firma. J Hazard Mater 199-200:314-320

Suja F, Rahim F, Taha MR, Hambali N, Razali MR, Khalid A, Hamzah A (2014) Effects of local microbial bioaugmentation and biostimulation on the bioremediation of total petroleum hydrocarbons (TPH) in crude oil contaminated soil based on laboratory and field observations. Inter Biodeter Biodegr 90:115-122
Sun LN, Zhang YF, He LY, Chen ZJ, Wang QY, Qian M, Sheng XF (2010) Genetic diversity and characterization of heavy metalresistant-endophytic bacteria from two copper-tolerant plant species on copper mine wasteland. Bioresour Technol 101:501-509

Tiwari S, Sarangi BK, Thul ST (2016) Identification of arsenic resistant endophytic bacteria from Pteris vittata roots and characterization for arsenic remediation application. J Environ Manag 180:359-365

Weyens N, Truyens S, Saenen E, Boulet J, Dupae J, van der Lelie D (2010) Endophytes and their potential to deal with co-contamination of organic contaminants (toluene) and toxic metals (nickel) during phytoremediation. Int $\mathrm{J}$ Phytoremediation 13:244-255

Zhang YF, He LY, Chen ZJ, Zhang WH, Wang QY, Qian M, Sheng XF (2011) Characterization of lead-resistant and ACC deaminase-producing endophytic bacteria and their potential in promoting lead accumulation of rape. $\mathbf{J}$ Hazard Mater 186:1720-1725

Zhang WH, Chen W, He LY, Wang Q, Sheng XF (2015) Characterization of Mn-resistant endophytic bacteria from Mn-hyperaccumulator Phytolacca Americana and their impact on Mn accumulation of hybrid penisetum. Ecotox Environ Safe 120:369-376

Zhou Q, Chen Y, Yang M, Li W, Deng L (2013) Enhanced bioremediation of heavy metal from effluent by sulfate-reducing bacteria with copper-iron bimetallic particles support. Bioresour Technol 136:413-417

Zhu LJ, Guan DX, Luo J, Rathinasabapathi B, Ma LQ (2014) Characterization of arsenic-resistant endophytic bacteria from hyperaccumulators Pteris vittata and Pteris multifidi. Chemosphere 113:9-16 